\title{
A comparative study on Ca content and distribution in two Gesneriaceae species reveals distinctive mechanisms to cope with high rhizospheric soluble calcium
}

\author{
Wenlong $\mathrm{Li}^{1,2,3}$, Falun $\mathrm{Xu}^{4}$, Shixuan Chen ${ }^{1}$, Zhennan Zhang ${ }^{1}$, Yan Zhao ${ }^{1}$, Yukuan Jin ${ }^{1}$, Meijing $\mathrm{Li}^{1}$, \\ Yan Zhu ${ }^{1}$, Yongxiu Liu ${ }^{2}$, Yi Yang ${ }^{4}$ and Xin Deng ${ }^{1 *}$
}

${ }^{\prime}$ Key Laboratory of Plant Resources and Beijing Botanical Garden, Institute of Botany, The Chinese Academy of Sciences, Beijing, China

${ }^{2}$ Key Laboratory of Plant Molecular Physiology, Institute of Botany, Chinese Academy of Sciences, Beijing, China

${ }^{3}$ College of Life Sciences, University of Chinese Academy of Sciences, Beijing, China

${ }^{4}$ Key Laboratory of Bio-Resource and Eco-Environment, Ministry of Education, College of Life Sciences, Sichuan University, Chengdu, China

Edited by:

Jan Kofod Schjoerring, University of

Copenhagen, Denmark

Reviewed by:

Jon Pittman, University of

Manchester, UK

Elizabeth Pilon-Smits, Colorado

State University, USA

\section{*Correspondence:}

Xin Deng, Institute of Botany,

Chinese Academy of Sciences,

Xiangshan Nanxincun 20, Haidian

District, Beijing, 100093, China

e-mail: deng@ibcas.ac.cn
Excessive $\mathrm{Ca}$ is toxic to plants thus significantly affects plant growth and species distribution in Ca-rich karst areas. To understand how plants survive high Ca soil, laboratory experiments were established to compare the physiological responses and internal $\mathrm{Ca}$ distribution in organ, tissue, cell, and intracellular levels under different Ca levels for Lysionotus pauciflorus and Boea hygrometrica, two karst habitant Gesneriaceae species in Southwest China. In the controlled condition, L. pauciflorus could survive as high as $200 \mathrm{mM}$ rhizospheric soluble $\mathrm{Ca}$, attributed to a series of physiological responses and preferential storage that limited $\mathrm{Ca}$ accumulation in chloroplasts of palisade cells. In contrast, B. hygrometrica could survive only $20 \mathrm{mM}$ rhizospheric soluble $\mathrm{Ca}$, but accumulated a high level of internal $\mathrm{Ca}$ in both palisade and spongy cells without disturbance on photosynthetic activity. By phenotype screening of transgenic plants expressing high Ca-inducible genes from $B$. hygrometrica, the expression of BhDNAJC2 in $A$. thaliana was found to enhance plant growth and photosynthesis under high soluble Ca stress. BhDNAJC2 encodes a recently reported heat shock protein (HSP) 40 family DnaJ-domain protein. The Ca-resistant phenotype of BhDNAJC2 highlights the important role of chaperone-mediated protein quality control in Ca tolerance in B. hygrometrica. Taken together, our results revealed that distinctive mechanisms were employed in the two Gesneriaceae karst habitants to cope with a high Ca environment.

Keywords: Boea hygrometrica, Lysionotus pauciflorus, karst plant, heat shock protein, chaperon, high Ca stress, photosynthesis and the environment

\section{INTRODUCTION}

Crops and vegetables with high Ca contents are potential sources of dietary Ca for human use (Dayod et al., 2010). Fertilization and biofortification via transgenic manipulation have been used to increase calcium in food crops. However, the progress has been limited, essentially because that excessive intracellular calcium causes toxicity to plants. Though $\mathrm{Ca}$ is an essential macronutrient for plants with key structural and signaling roles (Dayod et al., 2010; Gilliham et al., 2011), excessive intracellular Ca can precipitate with phosphates, prevent seed germination, disturb photosynthesis, reduce growth rate and form tiny yellowish or gold spots of fruits (Chan et al., 2003; White and Broadley, 2003). Ca is mainly obtained from the soil solution through the root system in the form of $\mathrm{Ca}^{2+}$, and transported in the xylem from root to shoot driven by transpiration pull and soil $\mathrm{Ca}^{2+}$ concentration (White, 2001; Conn and Gilliham, 2010). Ca becomes relatively immobile once having been transported into cells (Malone et al., 2002). Thus, external Ca supply and transpiration have major impacts on the amount of plant internal $\mathrm{Ca}$. Many plants decrease transpiration when external Ca elevates to limit Ca uptake (Silva et al., 1996; Tang et al., 2007). Therefore, finding a way to control plants $\mathrm{Ca}$ and accumulation without disturbing normal growth and survival under high Ca condition is a key step for generation of plants with high Ca contents.

Karst terrain is famous for Ca-rich soil, which has been one of the major factors that limit the species and production of crops and vegetables that could be cultivated. However, it is an undeniable natural advantage for cultivation of crops and vegetables with high Ca contents. Moreover, the native habitant plants in karst area have provided valuable resources for understanding how plants survive high Ca. Our previous survey on the plants in karst mountainous area in Southwest China have revealed a number of plants that always kept low internal Ca contents in aboveground tissues regardless of the high calcium level in soil (High-Ca type), that always accumulated high internal Ca contents even in the relatively low calcium soil (Low-Ca type), and that could varied their Ca contents in accordance with soil Ca contents (Variable-Ca type) (Ji et al., 2009). Understanding how these plants absorb, transport, store and tolerate high level internal Ca in Ca-rich soil will pave the way for generation of crops 
and vegetables that contain high Ca contents, and that could be cultivated in karst area. Such effort will eventually benefit the development of agriculture, ecosystem and economics in the vast karst regions, which accounts for about $15 \%$ of the world's land area or about 2.2 million $\mathrm{km}^{2}$, and is home for around 1 billion people ( $17 \%$ of the world's population).

Lysionotus pauciflorus and Boea hygrometrica are two species in Gesneriaceae family, both native habitants in karst rocky areas in Southwest China (Wang et al., 2005). L. pauciflorus is a small shrub with procumbent small stolons or rhizome, while B. hygrometrica is a kind of herb that has been well characterized as a resurrection plant, whererby its vegetative organs can tolerate extreme dehydration (Mitra et al., 2013). Several genes and proteins have been identified to play roles in desiccation tolerance in B. hygrometrica and other Gesneriaceae resurrection plants (Jiang et al., 2007; Liu et al., 2009; Zhao et al., 2014; Chen et al., in press), yet no information at the molecular level has been obtained for understanding how these plants cope with high $\mathrm{Ca}$ soil so far. In this study, a survey on the rhizospheric Ca contents of karst plants in Southwest China revealed that L. pauciflorus exhibited the highest amount of soluble $\mathrm{Ca}$ in the rhizospheric soil among all tested species. We then performed laboratory experiments to compare the threshold of the external soluble Ca that $L$. pauciflorus and B. hygrometrica could survive, the physiological responses and internal $\mathrm{Ca}$ distribution in different organs, tissues and cell types under different rhizospheric calcium application. The possible mechanisms that plants employed to survive high calcium in L. pauciflorus and B. hygrometrica were discussed.

\section{MATERIALS AND METHODS PLANT MATERIALS AND TREATMENTS}

Plants of 10 species, namely Eriophorum comosum, Oplismenus undulatifolius, Cyrtomium fortunei, Pieris multifida, Selaginella moellendorffii, Corchoropsis tomentosa, Eupatorium adenophorum, Boea hygrometrica, Lysionotus pauciflorus, Paraboea rufescens, were collected from typical karst regions in Libo $\left(107^{\circ} 44^{\prime} \mathrm{E}, 25^{\circ} 15^{\prime} \mathrm{N}\right)$, Luodian $\left(106^{\circ} 51^{\prime} \mathrm{E}, 25^{\circ} 33^{\prime} \mathrm{N}\right)$, Huajiang $\left(105^{\circ} 36^{\prime} \mathrm{E}, 25^{\circ} 41^{\prime} \mathrm{N}\right)$, and Puding $\left(105^{\circ} 45^{\prime} \mathrm{E}, 26^{\circ} 14^{\prime} \mathrm{N}\right)$ in Guizhou province of China. Young plants of L. pauciflorus and B. hygrometrica were grown in quartz sand with irrigation of 1/2 strength Hoagland nutrient solution (Hoagland and Arnon, 1950) in a greenhouse. After 15 days, different concentrations of $\mathrm{Ca}\left(\mathrm{NO}_{3}\right)_{2}$ were applied with $1 / 2$ strength Hoagland nutrient solution for 7 days. For L. pauciflorus and B. hygrometrica, photographic and physiological records were only documented for five concentrations, 2.5 (control), 20, 60, 100, and $200 \mathrm{mmol} \cdot \mathrm{L}^{-1}$, because all leaves of $\mathrm{L}$. pauciflorus dropped when plants were treated with $350-900 \mathrm{mmol} \cdot \mathrm{L}^{-1} \mathrm{Ca}\left(\mathrm{NO}_{3}\right)_{2}$ and no leaf was available for physiological measurement.

\section{DETERMINATION OF Ca CONTENTS IN SOIL AND IN PLANT}

Rhizosphere soil samples were prepared by collecting soil surrounding the roots of individual plants from the native habitats. Soil samples were oven-dried, and passed through a 2-mm sieve. Then $5 \mathrm{~g}$ samples were soaked in $50 \mathrm{~mL}$ deionized water (for soluble $\mathrm{Ca}$ ) or $1 \mathrm{~mol} \cdot \mathrm{L}^{-1} \mathrm{NH}_{4} \mathrm{COOH}$ (for exchangeable $\mathrm{Ca}$ ) and shaken for $30 \mathrm{~min}$. The mixture was filtered quickly. $1 \mathrm{~mL} 10 \%$ $\mathrm{La}\left(\mathrm{NO}_{3}\right)_{3}$ was then added to $10 \mathrm{~mL}$ filtrate.

Aboveground and underground parts of plants were washed with deionized water and blotted dry. The samples were then dried at $80^{\circ} \mathrm{C}$ for $48 \mathrm{~h}$ in an oven. Dried samples were ground, and $0.2 \mathrm{~g}$ of the powder was digested in $\mathrm{H}_{2} \mathrm{SO}_{4}: \mathrm{H}_{2} \mathrm{O}_{2}(5: 3, \mathrm{v} / \mathrm{v})$.

$\mathrm{Ca}$ content was determined by Atomic Absorption Spectrophotometer (5100 PC, the Perkin-Elmer Corporation, USA) (Mizuno and Minami, 1980).

\section{NET PHOTOSYNTHETIC RATE, STOMATAL CONDUCTANCE, WATER CONTENT, AND TRANSPIRATION RATE}

Net photosynthetic rate, stomatal conductance, and transpiration rate were determined using LI-6400XT portable photosynthesis system (LI-6400XT, LI-COR, USA) (Lü et al., 2010). Net photosynthetic rate was computed by measuring the rate of change of $\mathrm{CO}_{2}$ with time with a leaf enclosed in a relatively large chamber as follow: Net photosynthetic rate $=\mathrm{F} \times[\mathrm{Cr}-\mathrm{Cs} \times$ $((1000-\mathrm{Wr}) /(1000-\mathrm{Ws}))] / 100 \mathrm{~S}$. F represents flow rate to the sample chamber $\left(\mu \mathrm{mol} \cdot \mathrm{s}^{-1}\right)$. $\mathrm{Cr}$ and $\mathrm{Cs}$ represent $\mathrm{CO}_{2}$ concentration of reference chamber and sample chamber $\left(\mu \mathrm{mol} \mathrm{CO}_{2}\right.$ $\mathrm{mol}^{-1}$ ), respectively. Wr and $\mathrm{Ws}$ represent $\mathrm{H}_{2} \mathrm{O}$ concentration of reference and sample chamber $\left(\mathrm{mmol} \mathrm{H}_{2} \mathrm{O} \mathrm{mol}{ }^{-1}\right)$, respectively. $\mathrm{S}$ represents leaf area. Plant samples were oven-dried for $48 \mathrm{~h}$ and water content was calculated as: Water content $=($ Fresh weight Dry weight)/Fresh weight $\times 100 \%$.

\section{SEM X-RAY MICROANALYSIS}

Plant leaves were frozen in liquid $\mathrm{N}$ and fractured with pre-cooled razor blades and then freeze-dried using a vacuum freeze-drier at $-80^{\circ} \mathrm{C}$ for 3 days, to ensure that the water in biological materials can be removed with optimized structure preservation, and cellular mobile macromolecules and mobile ions can be stabilized without redistribution (Edelmann, 2002). Low temperature was kept to avoid possible Ca redistribution during sample preparation, as suggested by Edelmann (2002). Dried samples were mounted on aluminum stubs, and coated with gold. Elemental analysis was performed using an energy-dispersive X-ray microanalysis system (EMAX 350, Horiba, Japan) fitted to a HITACHI S-4800 scanning electron microscope (SEM) (Hitachi, Japan). The acceleration voltage used was $20 \mathrm{kV}$. X-ray spectra were collected for $180 \mathrm{~s}$ each. At least three replicates of X-ray line scans were obtained for each sample and three independent analyses were performed. The signal of endogenous magnesium was used as a reference to evaluate the effects of variation of surface topography between the different selected cells on the efficiency of SEM X-ray rate counting (Olmos and Hellin, 1998; Peng et al., 2004; Fernandez-Garcia et al., 2009).

\section{${ }^{45}$ Ca FEEDING AND AUTORADIOGRAGHY}

L. pauciflorus and B. hygrometrica seedlings grown in unstressed condition were used for ${ }^{45} \mathrm{Ca}$-feeding experiments. Radioactive ${ }^{45} \mathrm{Ca}$ was added proportionally into $1 / 2$ strength Hoagland nutrient solution containing different concentrations of $\mathrm{Ca}$ to final activities as follows: $0.2 \mathrm{MBq} \mathrm{ml}^{-1}(2.5 \mathrm{mM}), 2 \mathrm{MBq} \mathrm{ml}^{-1}$ $(20 \mathrm{mM})$, and $20 \mathrm{MBqml}^{-1}(200 \mathrm{mM})$. Plants were transferred to quartz sand and irrigated with the nutrition solution containing 
relative ${ }^{45} \mathrm{Ca}$ content for 7 days. Eight plants were treated for each condition. Four plants were used for autoradiography of ${ }^{45} \mathrm{Ca}$ in a dark room, and the rest for radioactivity measurement using a liquid scintillation counter (XH-6925, China) (Busse and Palta, 2006; Kerton et al., 2009).

\section{Fluo-3 AM STAINING}

Transverse sections of the leaves were prepared using two razor blades in MES buffer ( $25 \mathrm{mM}, \mathrm{pH}$ 6) to minimize wound effect. Pluronic F-127 (20\% in dimethylsulfoxide, Invitrogen, USA) was mixed (1:1) with the stock solutions of Fluo-3 AM $(11.05 \mathrm{mM}$ stock in dimethylsulfoxide, Invitrogen, USA), before addition of MES buffer. The sections were stained at $4^{\circ} \mathrm{C}$ for $2 \mathrm{~h}$ in the dark with $22.1 \mu \mathrm{M}$ Fluo-3 AM mixed with $0.04 \%$ Pluronic F-127 in MES buffer ( $25 \mathrm{mM}, \mathrm{pH}$ 6). Low temperature was kept to avoid cleavage of acetoxymethyl group from fluo-3 AM by extracellular esterases that activate the probe, as suggested and Zhang et al. (1998). After staining, the sections were washed in MES buffer for $2 \mathrm{~h}$ at $20^{\circ} \mathrm{C}$ in the dark. The fluorescence signal was observed using a Zeiss LSM 510 META confocal laser scanning microscope (Zeiss Microsystems, Germany) using excitation at $488 \mathrm{~nm}$. The emission was detected at $515-580 \mathrm{~nm}$ for Fluo-3 AM (Zhang et al., 1998; Albrechtova et al., 2003; Zienkiewicz et al., 2011).

\section{EXAMINATION OF STRESS TOLERANCE IN TRANSGENIC ARABIDOPSIS}

Transgenic Arabidopsis thaliana plants overexpressing B. hygrometrica genes BhC2DP1, BhDNAJC2, and BhOAR1 were obtained previously (Zhang et al., 2012; Zhao et al., 2014; Chen et al., in press). Seeds of T3 generation of three homozygous lines of each gene were surface sterilized and germinated on 1/2 Murashige and Skoog (MS) agar plates in parallel with wild-type controls at $22^{\circ} \mathrm{C}$ with a $16 \mathrm{~h}$ light $/ 8 \mathrm{~h}$ dark cycle. Three day-old seedlings were transferred to $1 / 2 \mathrm{MS}$ agar plates containing $60 \mathrm{mM} \mathrm{CaCl}_{2}$ for high-Ca stress phenotyping. The position of the seed lots were kept consistent in each treatment in one set of experiments but arranged randomly in different sets of repetitions. At least three independent experiments were conducted with three plates and 6 seedlings per line per plate were assayed. Photographs were taken, primary root length and physiological parameters were determined after 10 days of growth. In all cases, only wild-type seed batches that were generated in parallel with the transgenic seed lines were used for controls. Photochemical efficiency (Fv/Fm) and the extent of electrolyte leakage were measured as described previously (Jiang et al., 2007; Chen et al., in press).

\section{RNA ISOLATION AND REAL-TIME PCR}

Total RNA was isolated using the trizol method with TRIzol Reagent (Takara, D9108B). After digestion with DNase I, it was reverse transcribed into cDNA with Oligo(dT) 18 primer using SuperScript III reverse transcriptase, and used as template for PCR amplification. 18S rRNA was used as internal references. Real-time PCRs were performed in a Mastercycler ${ }^{\circledR}$ ep Realplex apparatus (Eppendorf, Hamburg, Germany) with SYBR ${ }^{\circledR}$ Green Real-time PCR Master Mix (TOYOBO, Japan). The relative expression levels were determined using $2^{-\Delta \Delta \mathrm{Ct}}$ method (Livak and Schmittgen, 2001). The expression level of each transcript was measured in three independent biological samples with three technical replicates.

\section{STATISTICAL ANALYSIS}

All data were subjected to a One-Way ANOVA followed by DUNCAN (alpha $=0.05$ ) test using SAS9.2, and expressed as means \pm standard deviation. Each data was obtained from at least three samples.

\section{RESULTS}

\section{PAUCIFLORUS TOLERATE HIGH RHIZOSPHERIC SOLUBLE Ca}

The calcium content in calcareous soils in Southwest China karst areas is 2-3 times more than that in red and yellow soil (Cao et al., 2003). To investigate the capacity of karst plants to survive high Ca environment, plants and rhizospheric soils of 10 species that were commonly found in Southwest China karst areas, including 3 ferns (C. fortunei, P. multifida and S. moellendorffii), 2 grasses (E. comosum and O. undulatifolius), and 5 dicots (C. tomentosa, E. adenophorum and three species of Gesneriaceae, e.g., B. hygrometrica, L. pauciflorus, and P. rufescens), were collected from their natural habitats and determined for total Ca contents. The results showed that the levels of exchangeable $\mathrm{Ca}$ content in the rhizospheric soils were similar among these plants $(1382-1752 \mathrm{mg} / \mathrm{kg})$, which were $2-5$ fold higher than that in loamy sand $(300 \mathrm{mg} / \mathrm{kg})$, silt loam $(650 \mathrm{mg} / \mathrm{kg})$, and sand loam $(700 \mathrm{mg} / \mathrm{kg}$ ) (Simmons and Kelling, 1987; Gunter and Palta, 2008). The highest soluble Ca content of the rhizosphere soils was found with L. pauciflorus (nearly $600 \mathrm{mg} / \mathrm{kg}$ ), which was significantly higher than the others (143-320 mg/kg) (Figure 1). On the other side, Ca content in shoots and roots of L. pauciflorus were similar to B. hygrometrica $(1.6 \%)$ and $P$. rufescens $(1.2 \%)$, but higher than some of the other species tested. These data suggest that L. pauciflorus exhibits extraordinary ability to cope with high soluble $\mathrm{Ca}$ in the rhizosphere.

\section{THE RANGES OF EXTERNAL Ca CONCENTRATIONS THAT $L$. PAUCIFLORUS AND B. HYGROMETRICA CAN SURVIVE}

The soluble Ca content of the rhizosphere soil of L. pauciflorus and $B$. hygrometrica in the karst area was nearly $600 \mathrm{mg} / \mathrm{kg}(15 \mathrm{mmol} / \mathrm{kg})$ and $200 \mathrm{mg} / \mathrm{kg}(5 \mathrm{mmol} / \mathrm{kg})$, respectively. However, these values do not represent the threshold of high Ca stress that L. pauciflorus and B. hygrometrica could survive. To quantitatively define the tolerance and the threshold of external high $\mathrm{Ca}$ conditions for both plants, a laboratory experimental system was established to cultivate plants under high $\mathrm{Ca}$ treatments by adding $2.5-900 \mathrm{mM} \mathrm{Ca}\left(\mathrm{NO}_{3}\right)_{2}$ in sand. This system can effectively monitor rhizospheric soluble Ca content in greenhouse conditions. It was shown that L. pauciflorus plants grew well under 2.5-200 mM external soluble $\mathrm{Ca}$ and no toxic symptoms were observed at least within a week (Figure 2A); however, leaves became yellowish and fell down under 350-900 mM $\mathrm{Ca}\left(\mathrm{NO}_{3}\right)_{2}$. In contrast, B. hygrometrica displayed obvious toxic symptoms such as curved leaves when 60 and $200 \mathrm{mM}$ Ca were applied (Figure 2A). L. pauciflorus could maintain active but slightly decreased photosynthesis activities under $20-200 \mathrm{mM}$ external $\mathrm{Ca}$ conditions. In comparison, B. hygrometrica could 

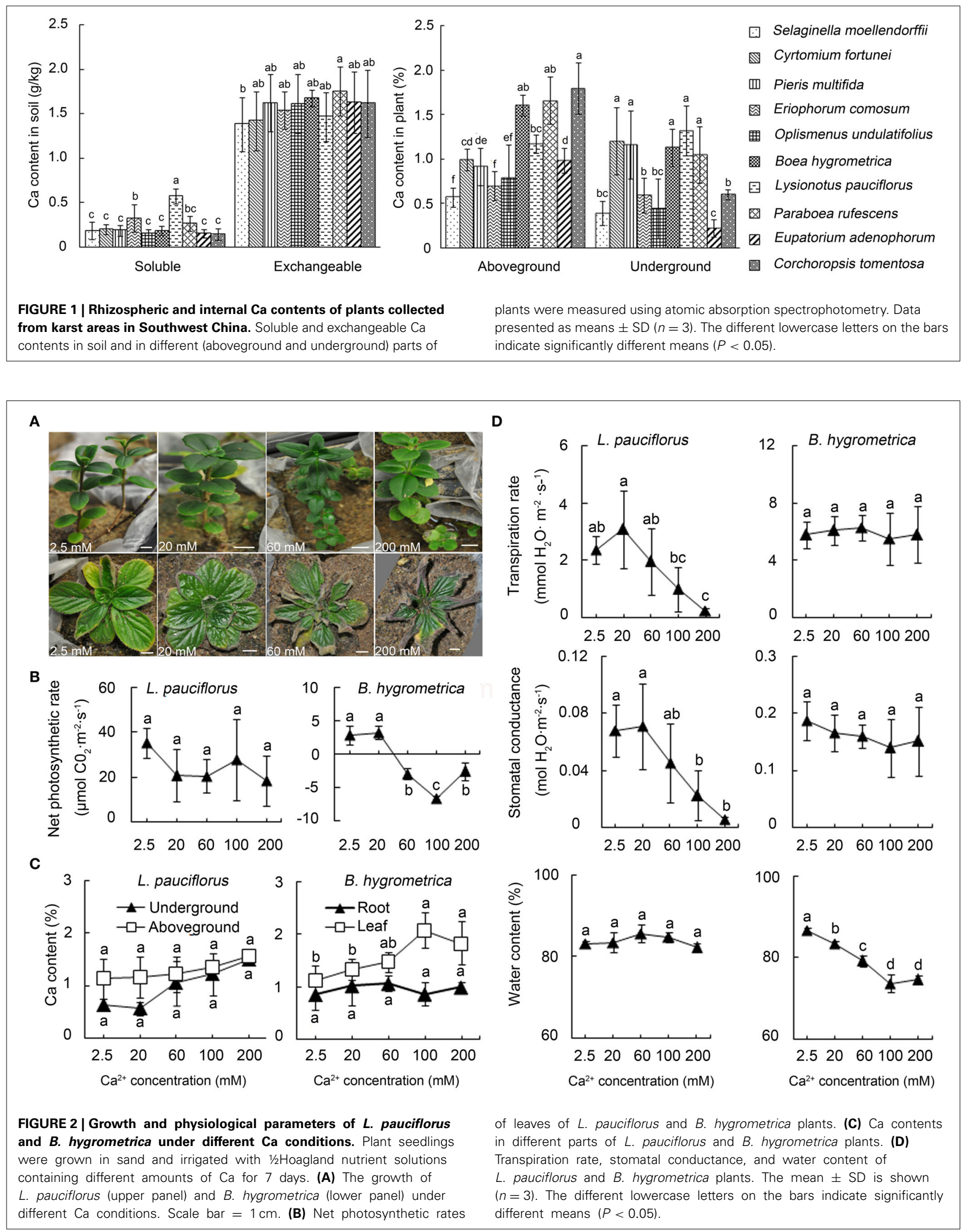
maintain a regular level of photosynthesis under moderate $\mathrm{Ca}$ stress (20 mM Ca), but dropped sharply under higher Ca treatments (Figure 2B). According to plant growth and photosynthetic activities, the highest rhizospheric soluble $\mathrm{Ca}$ threshold is $200 \mathrm{mM}$ for L. pauciflorus plants, and $20 \mathrm{mM}$ for B. hygrometrica under our cultivation conditions.

To determine whether the sensitivity to the above described treatments is due to high $\mathrm{Ca}$ rather than high $\mathrm{NO}_{3}^{-}$and high osmotic pressure, plants were also treated with $200 \mathrm{mM}$ (for L. pauciflorus) or $20 \mathrm{mM}$ (for B. hygrometrica) $\mathrm{CaCl}_{2}$ and $\mathrm{Mg}\left(\mathrm{NO}_{3}\right)_{2}$, respectively. Results showed that after 7 days, L. pauciflorus and $B$. hygrometrica plants under $\mathrm{Ca}\left(\mathrm{NO}_{3}\right)_{2}$ and $\mathrm{CaCl}_{2}$ treatments grew normally, displaying similar levels of net photosynthetic rates, water contents, and osmolalities as plants under control condition (Figure S1). In contrast, symptoms of leaf chlorosis and falling (L. pauciflorus) or curling (B. hygrometrica) were observed for plants under the treatment of $\mathrm{Mg}\left(\mathrm{NO}_{3}\right)_{2}$ (Figures S1A,B). Net photosynthetic rates and relative water contents were not affected in $L$. pauciflorus but significantly dropped in B. hygrometric plants under $\mathrm{Mg}\left(\mathrm{NO}_{3}\right)_{2}$ treatment (Figure S1C). The osmolalities were $500 \mathrm{mmol} / \mathrm{kg}$ for all these $200 \mathrm{mM}$ salt solutions and $100 \mathrm{mmol} / \mathrm{kg}$ for $20 \mathrm{mM}$ salt solutions (data not shown), therefore the phenotypes observed were not due to high osmolar pressure of the applied salt solutions. $\mathrm{Mg}\left(\mathrm{NO}_{3}\right)_{2}$ treatments led to higher levels of osmolalities in plants (Figure S1C), compared to $\mathrm{Ca}(\mathrm{NO} 3)_{2}$ and $\mathrm{CaCl}_{2}$ treatments, further supporting that the $\mathrm{Ca}$ resistance of $L$. pauciflorus and B. hygrometrica is specific to $\mathrm{Ca}$, rather than another cation, or merely changes in water availability and osmotic pressure caused by the application of these salt solutions.

\section{THE ACCUMULATION OF Ca IN ABOVEGROUND AND UNDERGROUND PARTS OF PLANTS AFTER HIGH Ca TREATMENT}

The effects of external high $\mathrm{Ca}$ on the plant internal $\mathrm{Ca}$ content were monitored by measuring the $\mathrm{Ca}$ contents in aboveground and underground parts of plants under different $\mathrm{Ca}$ levels. For L. pauciflorus, Ca contents were slowly increased from $1.1 \%$ to $1.6 \%$ in the aboveground part, and from 0.6 to $1.5 \%$ in the underground part, when plants were treated with 2.5-200 mM (Figure 2C). In contrast, root Ca content was stable at about $0.9-1 \%$ in B. hygrometrica when external $\mathrm{Ca}$ was 2.5-200 mM, whereas leaf Ca content gradually climbed from 1.1 to $2.1 \%$ when external Ca was increased from 20 to $100 \mathrm{mM}$ and dropped to $1.8 \%$ when $200 \mathrm{mM}$ Ca was applied (Figure 2C). Compared to the plants summarized by Dayod et al. (2010), which contained $0.13-460 \mathrm{mg}$ Ca per $100 \mathrm{~g}$ dry weight, L. pauciflorus and B. hygrometrica plants possess 2.4-8461 fold higher internal $\mathrm{Ca}$ content, even under low $\mathrm{Ca}$ condition $(2.5 \mathrm{mM})$. Furthermore, these data revealed that underground organs could serve as a Ca sink to reduce the load to leaves in L. pauciflorus when external Ca increases, whereas the roots of B. hygrometrica could not.

\section{TRANSPIRATION, STOMATAL CONDUCTANCE, AND WATER CONTENT IN PLANTS UNDER EXTERNAL HIGH Ca CONDITION}

It had been demonstrated that transpiration rate was one of the major factors that drive the absorption and root-to-shoot transport of $\mathrm{Ca}$ in the xylem (Conn and Gilliham, 2010). Therefore, we examined the changes of transpiration rate, stomatal conductance and water content in plants grown under high external Ca. Data have shown that both transpiration and stomatal conductance were kept stable in $20 \mathrm{mM}$ treated L. pauciflorus plants, but decreased markedly with the increase of external $\mathrm{Ca}$ from 60 to $200 \mathrm{mM}$ (Figure 2D). In agreement, water contents remained at the stable levels in $L$. pauciflorus plants under all treatment. The decrease of transpiration may help to reduce $\mathrm{Ca}$ absorption and upwards transport in L. pauciflorus under high Ca condition. In comparison, no fluctuation of transpiration rate and stomatal conductance in B. hygrometrica was observed, which was supported by the drop of water content when plants were treated with 2.5-200 mM Ca (Figure 2D). These data implied that external $\mathrm{Ca}$ application affected plant water status, transpiration and stomatal closure in opposite manners in the two Gesneriaceae species. It is worth highlighting that L. pauciflorus appears to have a much lower stomatal conductance and transpiration rate anyway even under low $\mathrm{Ca}$ addition, suggesting that it is generally more suited to maintenance of water status.

\section{Ca UPTAKE IN L. PAUCIFLORUS AND B. HYGROMETRICA UNDER HIGH Ca CONDITIONS}

To detect Ca uptake and movement after the application of high Ca, seedlings of the two species were fed with ${ }^{45} \mathrm{Ca}$ for 7 days in the cultivation condition described above. Autoradiography revealed only faint signals in stolons of plants grown under $2.5 \mathrm{mM} \mathrm{Ca}$, intensive signals in stolons of plants grown under moderate Ca treatment $(20 \mathrm{mM})$, and massive signals in leaves, stems, stolons and roots of plants grown under high Ca treatment $(200 \mathrm{mM})$ (Figure 3A). The quantification of the radioactive intensity further confirmed that the ${ }^{45} \mathrm{Ca}$ radioactivity in stolons was higher than that in all the other organs under $2.5-20 \mathrm{mM}$ Ca conditions, indicating that stolons serve as a major underground $\mathrm{Ca}$ sink under moderate $\mathrm{Ca}$ conditions. The radioactivity in leaves and stems were higher than that in stolon and root, and a gradual decrease of ${ }^{45} \mathrm{Ca}$ strength from root to stem tip and leaf was observed in plants grown under $200 \mathrm{mM}$ Ca treatment (Figure 3B). This suggested that a large amount of $\mathrm{Ca}$ moved into leaves via stem when $200 \mathrm{mM}$ Ca was applied in rhizosphere.

To the contrary, in B. hygrometrica, autoradiography revealed very faint signals in leaves of the plants grown under $2.5 \mathrm{mM} \mathrm{Ca}$ treatment, and strong signals in the edges of leaves but no signal in roots of plants under $20 \mathrm{mM}$ Ca condition (Figure 3C). Quantification revealed that the Ca radioactive strength in leaves of $20 \mathrm{mM}$ Ca-treated B. hygrometrica was 6 fold of that of $2.5 \mathrm{mM}$ Ca-treated plants, and the Ca radioactive signals in roots of $20 \mathrm{mM}$ Ca-treated plants were 3 fold of that of $2.5 \mathrm{mM} \mathrm{Ca}$ treated plants (Figure 3D). The radioactive intensity in leaves of $20 \mathrm{mM}$ Ca-treated B. hygrometrica plants were much higher than that in leaves of $20 \mathrm{mM}$ Ca-treated L. pauciflorus plants, whereas the radioactive intensities in roots were similar between $20 \mathrm{mM}$ Ca-treated plants of L. pauciflorus and B. hygrometrica. These results indicated that a leaf is the main organ in B. hygrometrica for $\mathrm{Ca}$ accumulation under moderate $\mathrm{Ca}$ conditions. 


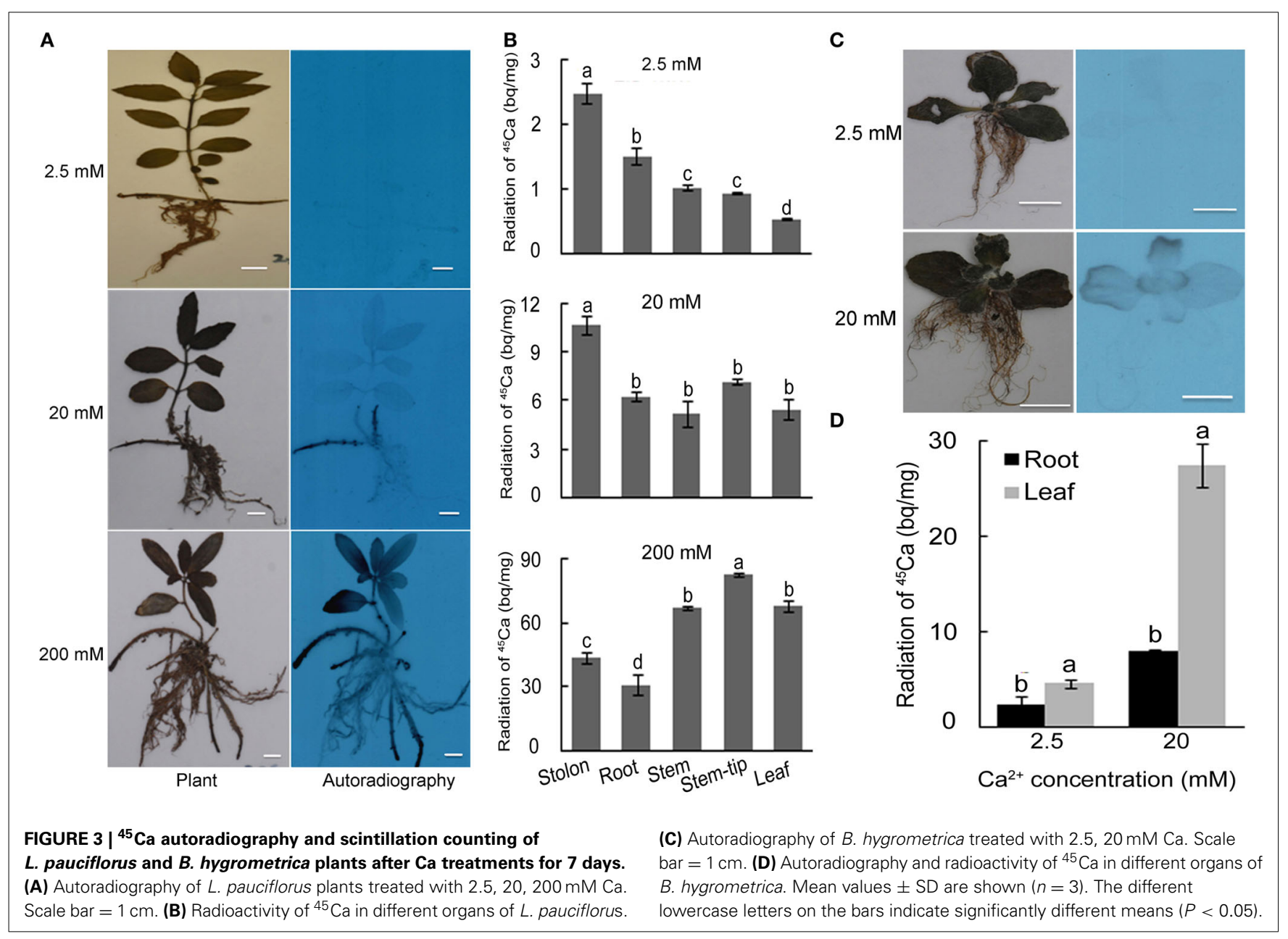

\section{Ca DISTRIBUTION IN DIFFERENT CELL TYPES OF LEAVES OF PLANTS UNDER HIGH CALCIUM}

L. pauciflorus leaves contain an amphicribral vascular bundle in the midrib (Figure 4A), a thick upper epidermis structure that is composed of one layer of parenchyma and two or three layers of large epithelial cells, a typical mesophyll structure that is composed of several layers of compact thin and small palisade cells and incompact middle-sized round spongy cells, and a hairless thin layer of lower epidermis cells (Figure 4B). As shown by SEM X-ray line profiles, a valley of Ca signal was detected in the vascular bundle in midribs in plants under all treatments, indicating the effective unloading to mesophyll cells (Figure 4A). The $\mathrm{Ca}$ intensities in spongy cells were always 2-3 fold more than that in palisade cells and upper epidermis in non-vein sections of leaves in all treatments (Figure 4B), indicating the spongy cells were main Ca storage locations in leaves.

SEM X-ray imaging confirmed our previous observation of the leaves of B. hygrometrica by TEM (Wang et al., 2009) and line profiles revealed that $\mathrm{Ca}$ contents in all cell types were significantly increased with the rise of external $\mathrm{Ca}$ concentration (Figure 5). Among all cell layers in both the vein and non-vein sections, $\mathrm{Ca}$ intensities were high in the upper and lower epidermis and relatively low in mesophyll cells under $2.5-20 \mathrm{mM}$ external Ca treatment (Figures 5A,B). This indicated that the epidermis and probably the hairs on it were the main sinks of $\mathrm{Ca}$ and mesophyll cells accumulated $\mathrm{Ca}$ when external $\mathrm{Ca}$ increased. The $\mathrm{Ca}$ distribution pattern was distinct from $\mathrm{Mg}$ distribution in both L. pauciflorus and B. hygrometrica leaves (Figures 4, 5), indicating the specific $\mathrm{Ca}$ accumulation pattern under high $\mathrm{Ca}$ conditions.

\section{FREE Ca DISTRIBUTION IN LEAVES OF L. PAUCIFLORUS AND $B$. HYGROMETRICA}

$\mathrm{Ca}^{2+}$ is the active form of $\mathrm{Ca}$ in living cells with important regulatory roles. Several photosynthetic functions are influenced by $\mathrm{Ca}^{2+}$ (Brand and Becker, 1984; Long et al., 2005). As described above, we have demonstrated that L. pauciflorus and B. hygrometrica can survive and keep reasonable levels of photosynthesis under high $\mathrm{Ca}$ conditions, despite that large amount of $\mathrm{Ca}$ accumulated in leaves. To detect $\mathrm{Ca}^{2+}$ concentrations and distributions in leaves of L. pauciflorus and B. hygrometrica, Fluo-3 AM was used to stain leaf sections. The results showed that the major Ca signals were detected as faint $\mathrm{Ca}$ fluorescence in the large and transparent upper epithelial cells that showed no chlorophyll autofluorescence, and the narrow palisade cells that were rich of chlorophyll autofluorescence, while considerable Ca fluorescence in the elliptical spongy cells that showed relatively 
A

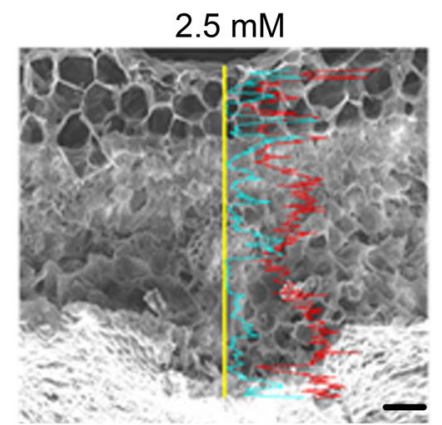

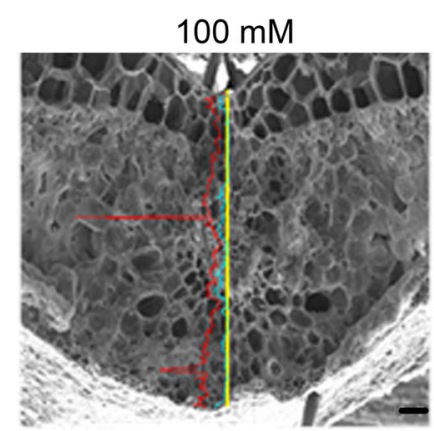
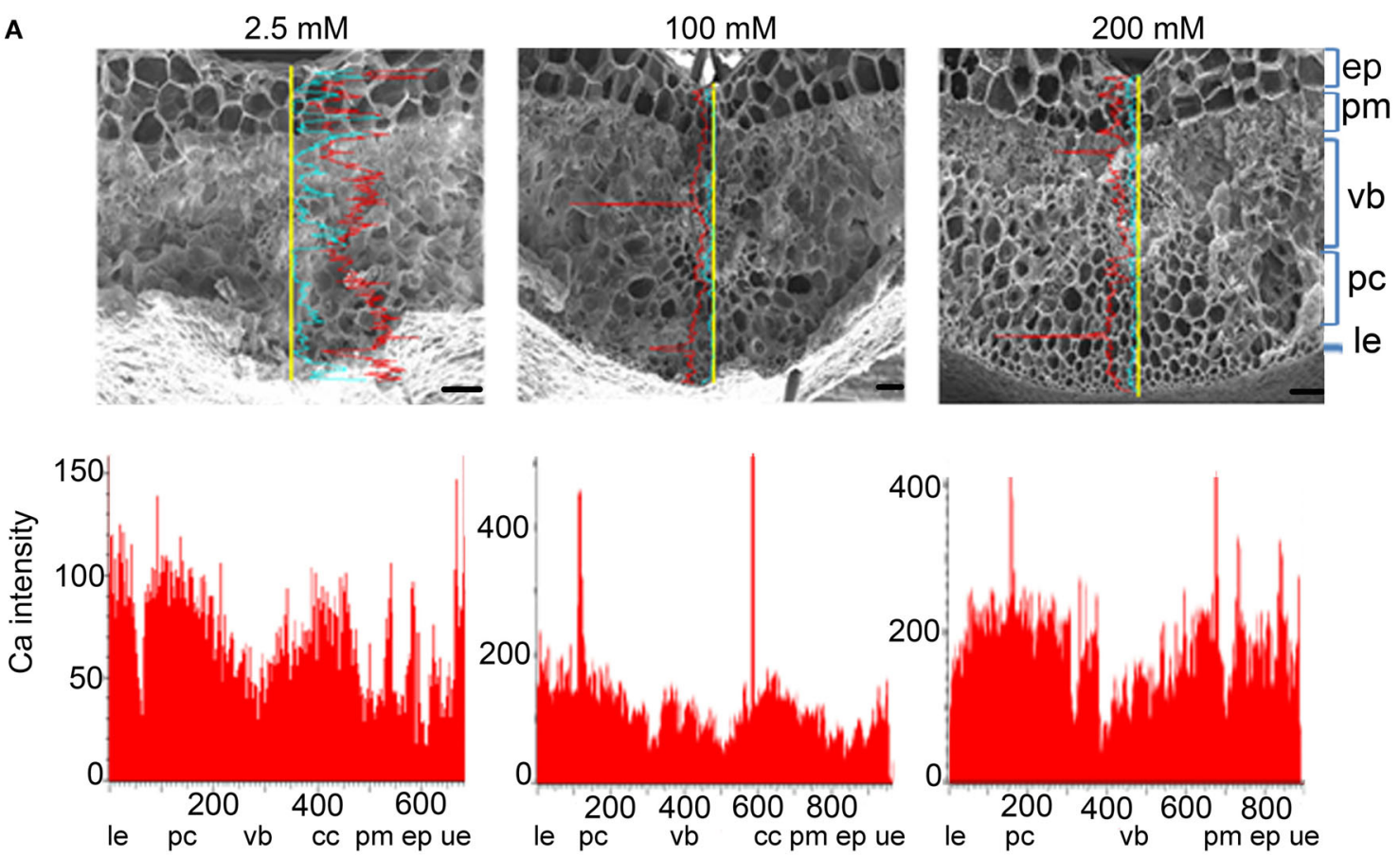

B
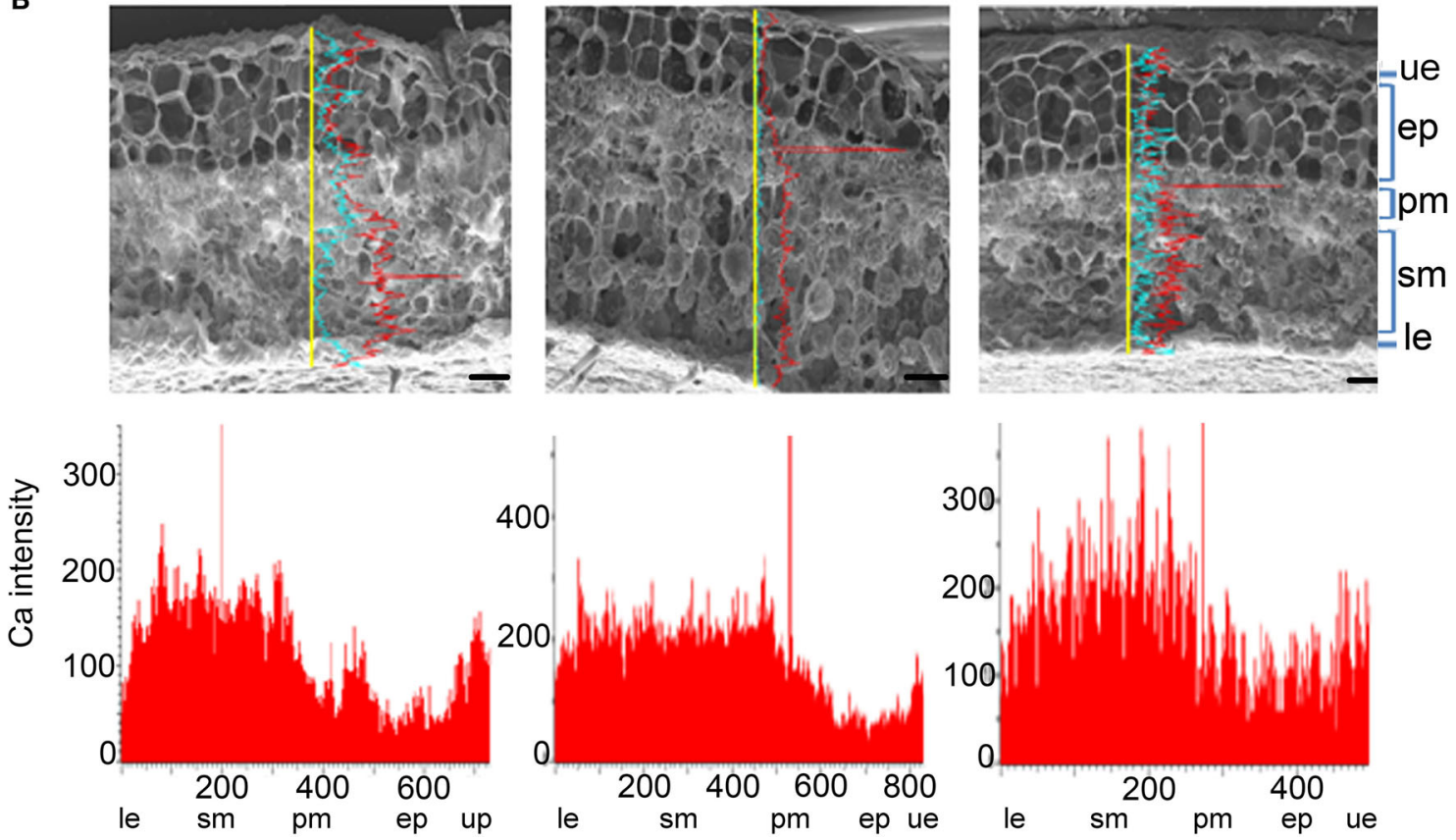

FIGURE 4 | $\mathrm{Ca}$ accumulation and distribution in the vein and non-vein parts of $L$. pauciflorus leaves. (A) Vein. (B) Non-vein. Ca content was

detected by SEM X-ray line profiles. Plants were treated with 2.5, 100, $200 \mathrm{mM}$

Ca concentrations respectively for 7 days. Yellow line, the scanning line. Red curve, Ca intensity counts. Blue curve, Mg intensity counts. Y-axis, Ca intensity counts; X-axis, position on line scan $(\mu \mathrm{m})$. Scale bar $=100 \mu \mathrm{m}$. ue, upper epidermis; pm, palisade mesophyll; cc, collenchyme; vb, vascular bundle; pc, parenchyma; ep, epithelial cells; sm, spongy mesophyll; le, lower epidermis. weak chlorophyll autofluorescence in plants under both 2.5 and $100 \mathrm{mM}$ Ca treatment (Figures 6A,B). Particularly strong Ca fluorescence signals were found in some spongy cells that scattered randomly, which are more abundant near the vein. At high magnification, it is observed that the strong Fluo-3 AM signals was likely from vacuoles in many of these cells as the vacuole comprises the majority of the volume of these cells and the Fluo-3 AM staining is smeared throughout the entirety of many of these cells. The Fluo-3 signals were not overlapped with chlorophyll autofluorescence, indicating that $\mathrm{Ca}^{2+}$ was not accumulated to high level in chloroplasts under normal and high Ca treatment (Figures 6C,D). 


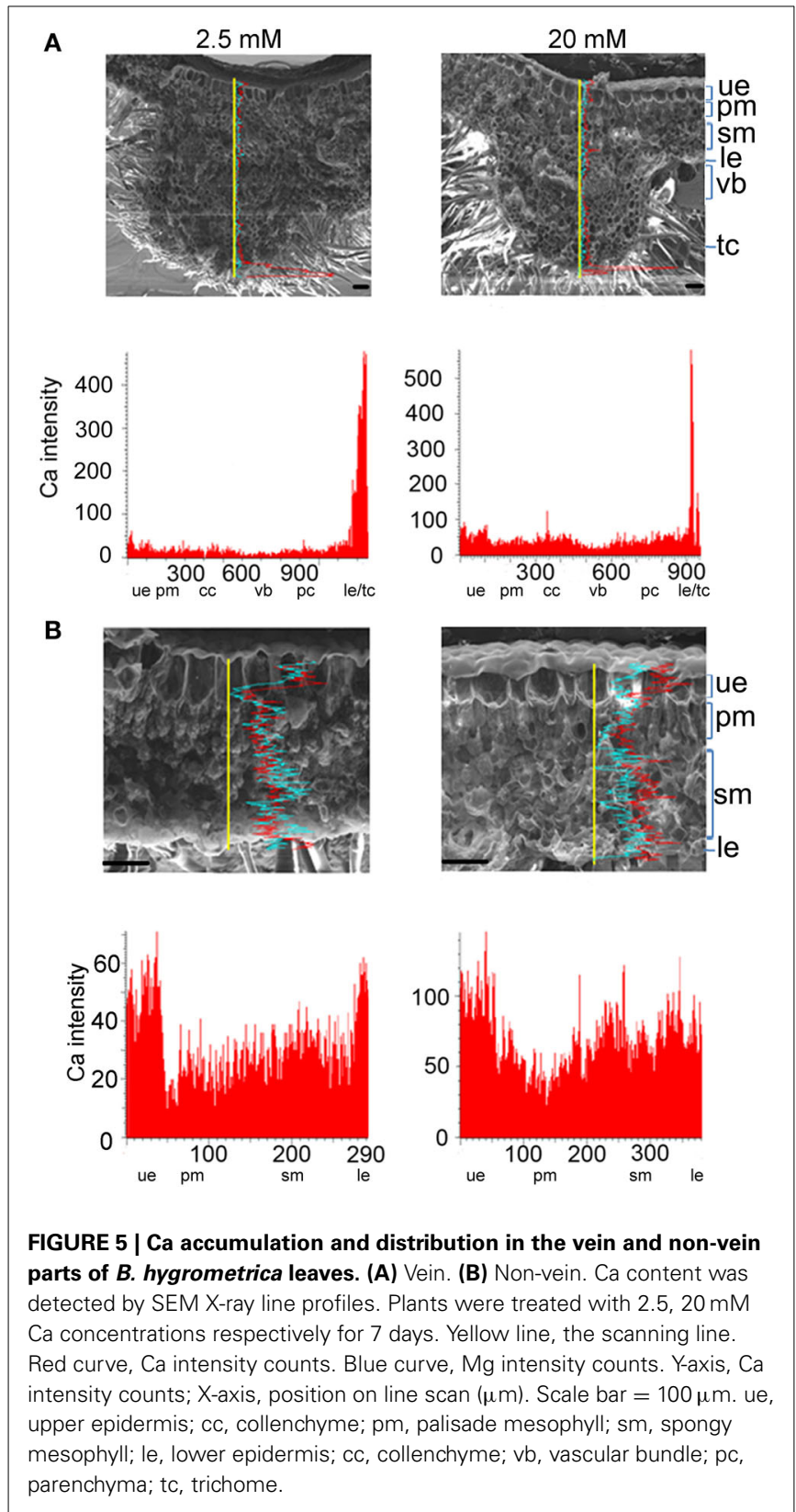

Fluo-3 AM staining showed a different pattern of $\mathrm{Ca}^{2+}$ distribution in leaves of $B$. hygrometrica. Weak fluorescence was detected in all cell types, and relatively stronger signals were found in vascular bundles and some cells that scattered randomly near the veins in $2.5 \mathrm{mM}$ Ca-treated plants (Figures 7A,B). The number of these $\mathrm{Ca}$-rich cells and the overall fluorescent intensity increased in $20 \mathrm{mM}$ Ca-treated plants (Figures 7A,B). Besides, fluorescence was very strong in trichomes on the abaxial surface of $20 \mathrm{mM}$ Ca-treated plants (Figure 7C). At high magnification, it was found that Fluo-3 AM signals in both palisade and spongy cells of 2.5 and $20 \mathrm{mM}$ Ca-treated plants were smeared inside cells and mostly co-localized with the chlorophyll autofluorescence, indicating a large amount of $\mathrm{Ca}$ in chloroplasts (Figures 7D-F). Furthermore, nearly no $\mathrm{Ca}^{2+}$ signal was observed in upper epidermal cells but strong $\mathrm{Ca}^{2+}$ signals could be found in the cuticle layer outside the upper epidermis, which was spread from palisade cells via the apoplastic space (Figure 7D).

\section{IDENTIFICATION OF Ca-INDUCIBLE GENES IN B. HYGROMETRICA THAT CONFERRED Ca-RESISTANT PHENOTYPE}

The observations described above have suggested that L. pauciflorus could prevent excessive $\mathrm{Ca}$ translocation to aboveground parts, leaves, palisade cells, and chloroplasts, thus limiting the harmful effects on photosynthesis and plant growth from high external soluble Ca stress. In contrast, B. hygrometrica could not avoid intracellular $\mathrm{Ca}$ accumulation in mesophyll cells even under low and moderate external soluble Ca environment, but could still keep active photosynthesis and normal growth. Given that such a trait is desired for the generation of Ca-rich crops/vegetables, it is meaningful to explore for genes with putative functions in $\mathrm{Ca}$ tolerance from $B$. hygrometrica. It was reported that $\mathrm{Ca}$ is preferentially stored in palisade and spongy cells in Arabidopsis, and Arabidopsis wild-type plants were severely impaired at $>30 \mathrm{mM}$ Ca application (Chan et al., 2003; Conn et al., 2011; Song et al., 2011). Thus, we used the previously generated transgenic Arabidopsis plants that overexpress B. hygrometrica genes to screen for Ca-resistant phenotype in $60 \mathrm{mM} \mathrm{CaCl} 2$ treatment. The tested genes included BhC2DP1 (Zhang et al., 2012), BhDNAJC2 (Chen et al., in press), and BhOAR1 (Zhao et al., 2014). BhC2DP1 encodes a plant-specific small protein with a single $\mathrm{Ca}^{2+}$-binding $\mathrm{C} 2$ domain, that had been reported to play a role in the crosstalk of $\mathrm{ABA}$ and $\mathrm{Ca}^{2+}$ signal pathway in response to drought stress (Zhang et al., 2012). BhDNAJC2 encodes a DnaJ-domain containing heat shock protein (HSP) 40 member with endoplasmic reticulum membrane retention signal (EFRG) and nuclear localization signal (RRKR) (Figure 8A). It had been shown to localize in the endoplasmic reticulum (ER), nucleus, and cytoplasm, and play a key role in the resistance to osmotic, saline, alkaline, and heat stresses (Chen et al., in press). BhOAR1 (B. hygrometrica Osmotic and Alkaline Resistance 1) encodes a 2 -kb retro-element sequence that confers improved photochemical efficiency under both osmotic and alkaline stresses when transformed to Arabidopsis (Zhao et al., 2014).

As expected, the wild-type Arabidopsis grew normally on $1 / 2$ MS plates, but became decolored, stunted and was dying when $60 \mathrm{mM} \mathrm{CaCl}_{2}$ was contained in the media. All the transgenic plants overexpressing BhOAR1 and BhC2DP1 were similar to wild-type under control and high $\mathrm{Ca}$ condition. Only plants overexpressing BhDNAJC2 were able to confer tolerance to high Ca stress, as indicated by the obvious better growth on $1 / 2 \mathrm{MS}$ plates containing $60 \mathrm{mM} \mathrm{CaCl}_{2}$, with bigger rosette, vivid and green leaves, and lower electrolytic leakage (Figures 8B-D). Moreover, the photochemical efficiency (Fv/Fm) was dramatically reduced in the wild-type plants under high Ca stress, but kept stable in the three lines of BhDNAJC2 overexpression transgenic plants (Figure 8D), suggesting the efficient protection of photosynthesis-related proteins to maintain their function. In agreement with the previously characterized expression levels of BhDNAJC2 in each transgenic line (Chen et al., in press), it was observed that OE8-7, the line with highest expression of BhDNAJC2, exhibited the strongest phenotypes. Together, 


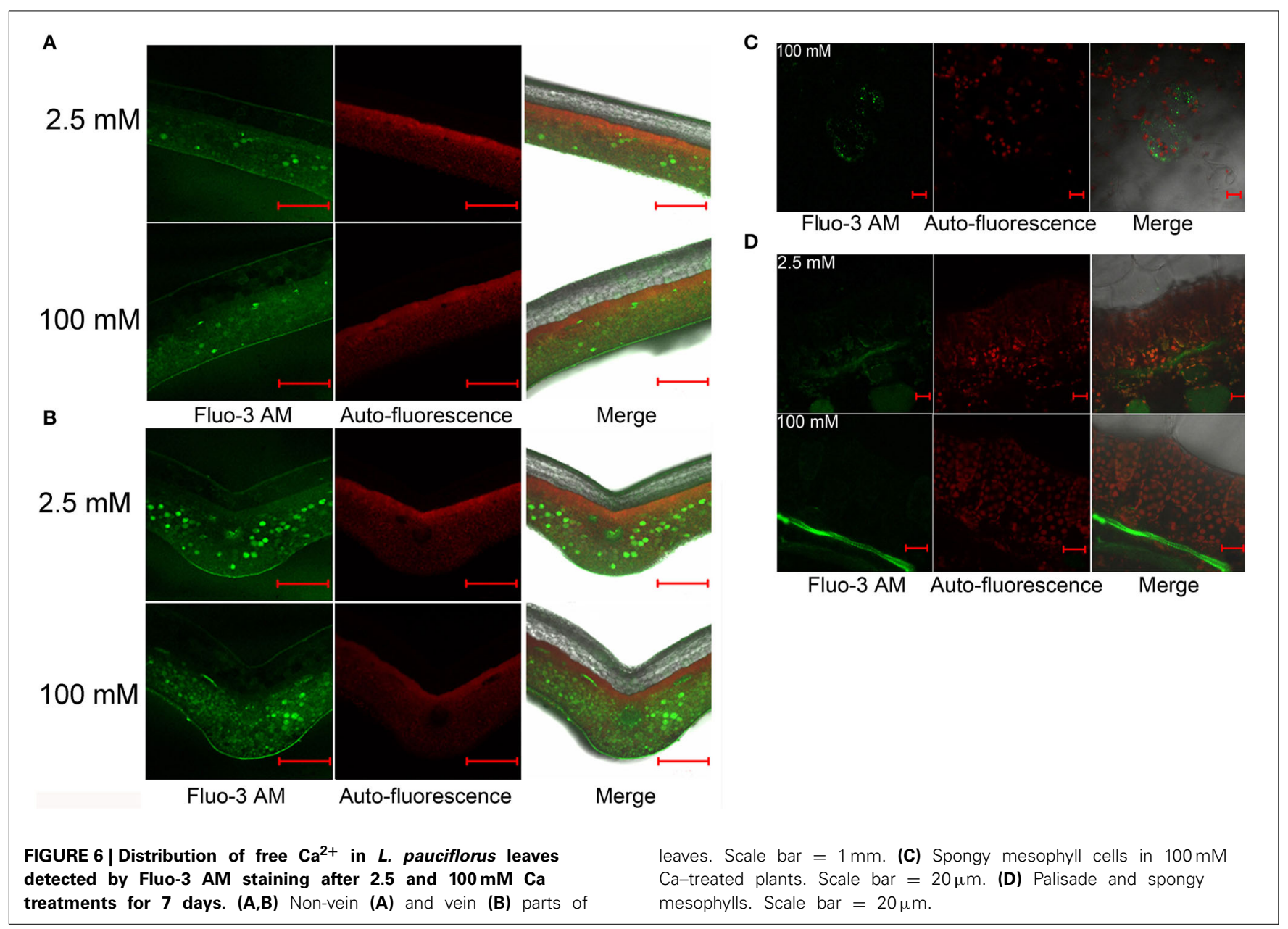

these data indicates that the degree of tolerance of overexpression lines to high $\mathrm{Ca}$ is correlated to the overexpression of BhDNAJC2.

Previously only slight induction of BhDNAJC2 expression was observed after $\mathrm{Ca}$ treatment for $2 \mathrm{~h}$ (Chen et al., in press). We further investigated the expression of this gene in B. hygrometrica under long-term high $\mathrm{Ca}$ stress. The results showed that BhDNAJC2 was highly induced by Ca stress for 4 and 6 days (Figure 9). These results supported that BhDNAJC2 may play an effective role in high Ca tolerance in B. hygrometrica.

\section{DISCUSSION}

Plants obtain Ca mainly from the soil solution (White, 2001). Soil in karst regions is rich in calcium, nearly three times more than in acid soils (Yuan, 2001; Cao et al., 2003). Not all plants are able to cope with such high external $\mathrm{Ca}$ in soil. For example, under laboratory experimental conditions, amaranth seedlings became stunted when external Ca was above $20 \mathrm{mM}$ (Aguilar-Hernandez et al., 2011). Arabidopsis ecotype Wassilewskija (Ws) was severely impaired at $30 \mathrm{mM} \mathrm{Ca}$ application (Chan et al., 2003). In this study, L. pauciflorus seedlings were found to survive as high as $200 \mathrm{mM}$ Ca without obvious growth defect or photosynthesis inactivation, demonstrating the extraordinary Ca tolerance of this species.
The root-to-shoot transportation of $\mathrm{Ca}$ in the xylem is driven by transpiration rate and soil $\mathrm{Ca}^{2+}$ concentration (Karley et al., 2000; Conn and Gilliham, 2010; Gilliham et al., 2011). In L. pauciflorus, the stomatal aperture and transpiration was obviously reduced with external $\mathrm{Ca}$ increase (Figure 2). A similar pattern was observed in Arabidopsis and Commelina communis (Silva et al., 1996; Tang et al., 2007). The quick response of stomatal closure may help to keep water content and normal physiological activities, thus representing a major factor for restricting $\mathrm{Ca}$ accumulation in L. pauciflorus. Besides, frequent drought stress is another major stress for plants inhabiting on the limestones in karst area. L. pauciflorus appears to have a much lower stomatal conductance and transpiration rate even under low Ca condition, suggesting that it is also suited to maintenance of water status. By contrast, in B. hygrometica, stomatal conductance, and transpiration were unchanged, which may account for the decrease of water content and photosynthesis under high Ca treatment. Previously it was observed that the stomata of B. hygrometrica were kept open under drought stress (Mitra et al., 2013). The unique regulation of stomata movement had been observed in many resurrection plants, while the molecular basis is still under investigation (Beckett et al., 2012; Gechev et al., 2012).

${ }^{45} \mathrm{Ca}$ autoradiography, scintillation counting, SEM X-ray, and Fluo-3 AM staining had been used to study $\mathrm{Ca}$ sinks and 


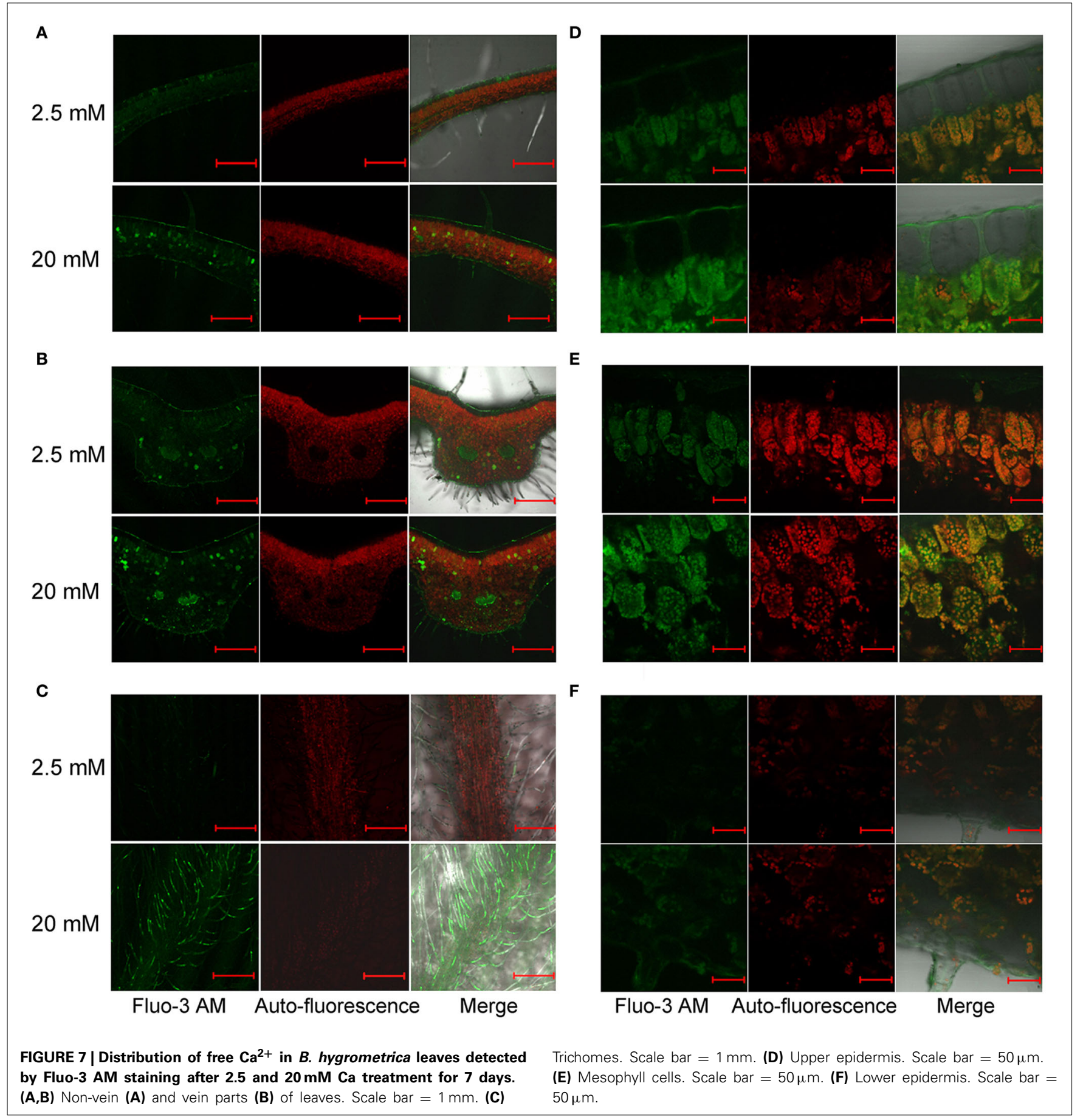

distribution in different organs, tissues, and cell types in many plants (Zhang et al., 1998; Albrechtova et al., 2003; Peng et al., 2004; Busse and Palta, 2006; Fernandez-Garcia et al., 2009; Kerton et al., 2009). Using these techniques we were able to show that the major Ca $\operatorname{sink}(\mathrm{s})$ in stolon (Figure 3), and the preferential Ca storage in spongy cell compared to palisade cells in leaves (Figure 6) in L. pauciflorus. Stolon was also observed to be a Ca sink in Oxalis acetosella (Rodenkirchen, 1998). Giving that Ca preferentially moved to organs with high meristematic activity (Lotscher and Hay, 1996), and the meristems of expanding underground organs are known for their high Ca demand (Rodenkirchen, 1998), the growing stolon could greatly restrict $\mathrm{Ca}$ translocation to the aboveground organs. The movement of $\mathrm{Ca}$ from stem into leaves was further blocked under high Ca conditions by certain mechanisms including reduced stomatal aperture and transpiration. The ability of $L$. pauciflorus to prevent excessive leaf $\mathrm{Ca}$ accumulation may prevent a degree of physiological toxicity due to Ca stress in contrast to B. hygrometrica. 


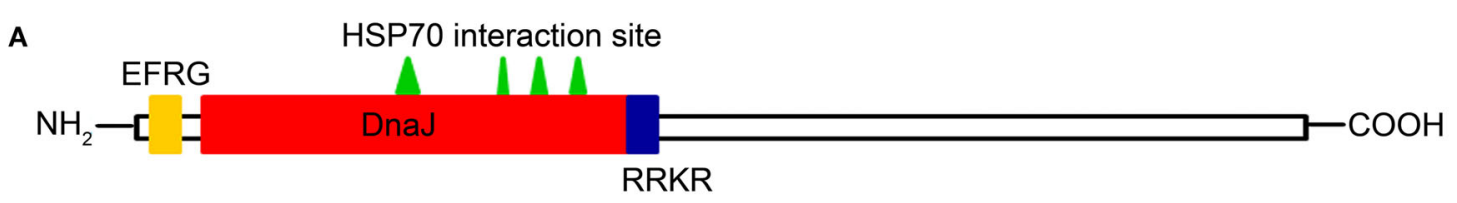

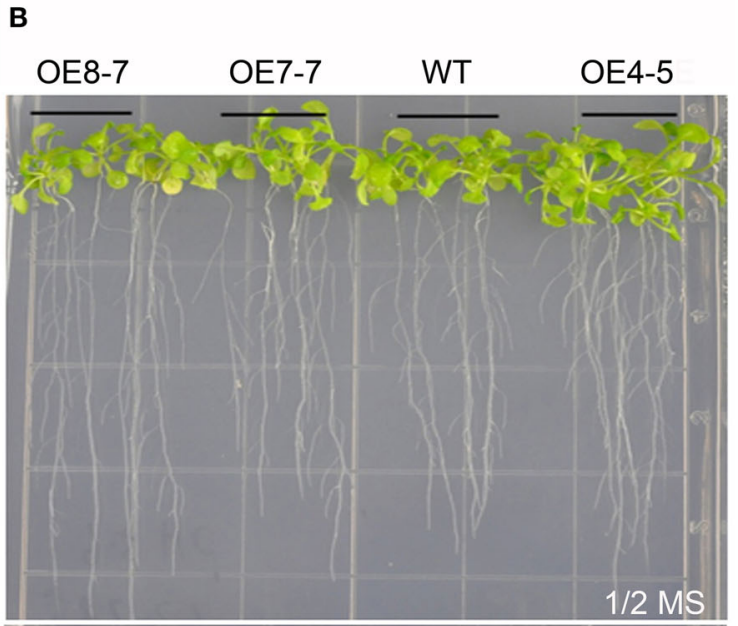

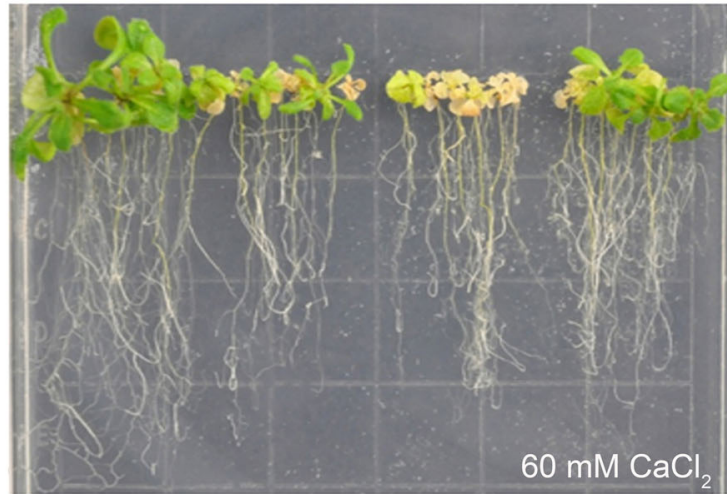

FIGURE 8 | Phenotype comparison of wild-type and transgenic plants overexpressing BhDNAJC2 under high calcium treatment. (A) Conserved domain of BhDNAJC2 protein. DnaJ, DnaJ domain; EFRG, endoplasmic reticulum membrane retention signal; RRKR, nuclear localization signal. (B) Arabidopsis seedlings grown on $1 / 2 \mathrm{MS}$ and $1 / 2 \mathrm{MS}+60 \mathrm{mmol} \cdot \mathrm{L}^{-1} \mathrm{CaCl}_{2}$
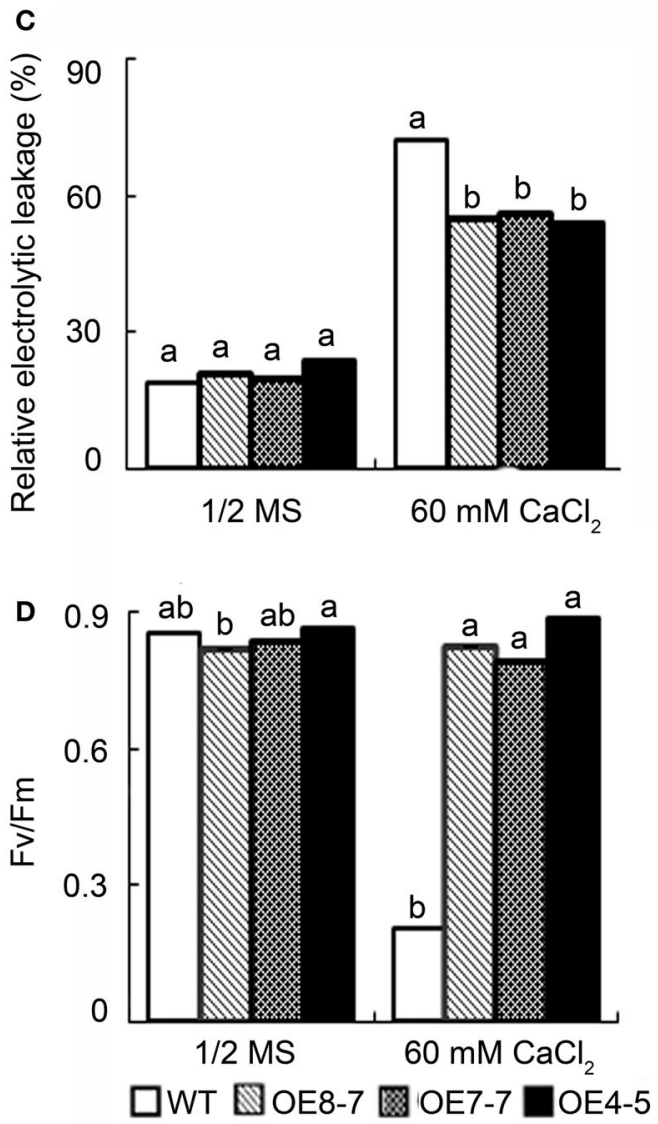

medium. Bar $=1 \mathrm{~cm}$. (C) Relative electrolytic leakage. (D) Photochemical efficiency (Fv/Fm). Data presented as means $\pm \mathrm{SD}(n=6)$. WT, wild-type; OE8-7, OE7-7, OE4-5, transgenic lines overexpressing BhDNAJC2. The different lowercase letters on the bars indicate significantly different means $(P<0.05)$
Palisade cells are the major sites for photosynthesis. Chloroplasts are unique organelles that are responsible for photosynthesis, but the increase in chloroplast $\mathrm{Ca}$ concentration will provoke the second ROS-burst, which is required to induce HR cell death in plants (Nomura et al., 2012). In these contexts, the preferential storage of $\mathrm{Ca}$ in spongy cells may help avoid $\mathrm{Ca}$ accumulation in palisade cells, thus contribute to the maintenance of active photosynthesis and cell vitality under high $\mathrm{Ca}$ environment. These observations, along with the observation that Fluo-3 AM detected free $\mathrm{Ca}^{2+}$ signals were not co-localized with chlorophyll auto-fluorescence (Figures 6C,D), have suggested that blocking $\mathrm{Ca}$ translocation to palisade cells and to chloroplasts may represent a second barrier to protect photosynthesis under high $\mathrm{Ca}$ condition. Cell-specific $\mathrm{Ca}^{2+}$ storage at tissue and cellular levels has been reported for many plants (Storey and Leigh, 2004; Kerton et al., 2009). It has been attributed to the different expression of particular $\mathrm{Ca}^{2+}$ transporters and $\mathrm{Ca}^{2+} / \mathrm{H}^{+}$-antiporters (Conn and Gilliham, 2010; Conn et al., 2011). For instance, CAX1 was preferentially expressed in Ca-rich mesophyll, and its function in controlling mesophyll $\mathrm{Ca}$ concentration and preventing epidermal Ca accumulation also provide $\mathrm{Ca}$ stress tolerance and regulate gas exchange (Conn et al., 2011).

In contrast to the ability to survive high Ca in L. pauciflorus, B. hygrometrica can only survive moderate Ca stress $(20 \mathrm{mM})$. However, the observations of higher $\mathrm{Ca}$ contents in leaves than that in roots (Figures 3C,D), the significant increase upon high $\mathrm{Ca}$ application (Figures 5, 7), the co-localization of $\mathrm{Ca}^{2+}$ signals with chlorophyll autofluorescence in both palisade and spongy cells (Figures 7D,E), and the consistent active photosynthesis (Figure 2) have indicated that B. hygrometrica has the ability to tolerate relatively high internal $\mathrm{Ca}$. It is likely that there are certain 


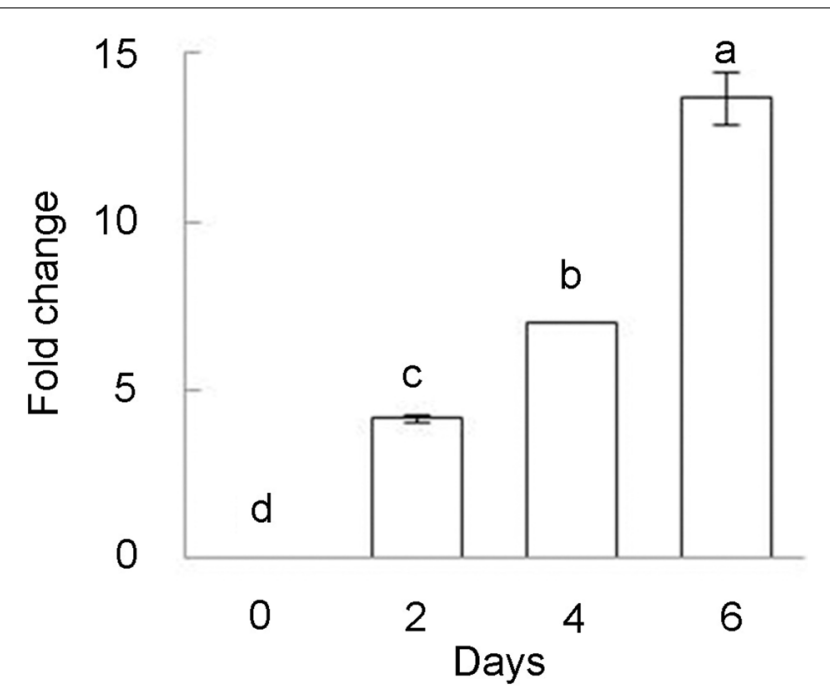

FIGURE 9 | Inducible expression of BhDNAJC2 under various high Ca treatments in $\boldsymbol{B}$. hygrometrica. Plants were treated with $20 \mathrm{mM} \mathrm{CaCl}_{2}$ for 2,4 , and 6 days. Mean values \pm SD are shown $(n=3)$. The different lowercase letters on the bars indicate significantly different means $(P<0.05)$.

mechanisms to minimize the harmful effects of excessive $\mathrm{Ca}$ and to protect photosynthetic apparatus in B. hygrometrica.

Abiotic stresses often interrupt protein folding, transportation, and stability, thus plastid protein homeostasis is critical during chloroplast biogenesis and responses to changes in environmental conditions. DnaJ proteins can interact with the ATPase domain of HSP70 and hydrolyse ATP to ADP, facilitating client capture (Kampinga and Craig, 2010), and function as molecular cochaperones of HSP70 in protein folding, unfolding, and assembly as well as in cellular secretory pathways (Walsh et al., 2004). ER-localized heat-shock protein HSP90.7 has been reported to function in resistance to tunicamycin or high calcium-induced ER stresses (Chong et al., in press). In this study, we demonstrated that BhDNAJC2 was significantly induced by long-term high Ca treatment (Figure 9), and the overexpression of BhDNAJC2 in Arabidopsis could improve plant growth and photosynthesis under high Ca stress (Figure 8). Both chloroplast-targeted chaperones that protect photosystem II and enzymes in the carbon fixation reaction, and various factors that facilitate protein targeting to chloroplasts including HSP70 and HSP90 have been identified (Liu et al., 2005; Chen et al., 2010; Ajjawi et al., 2011; Lee et al., 2013; Kong et al., 2014). It is not known whether cytosolic DnaJ proteins such as BhDNAJC2 are involved in protein targeting processes. However, our previous and present observations that Arabidopsis plants overexpressing BhDNAJC2 displayed better growth, higher Fv/Fm and lower electrolytic leakage under drought, salt, alkaline and heat stress conditions have suggested a general but effective role of BhDNAJC2 on safeguarding homeostasis and stabilization of proteins, including those related to photosynthesis under various environmental stresses (Chen et al., in press). However, a certain threshold concentration or expression level may limit the role of BhDNAJC2 in B. hygrometrica, for example, high expression of the gene in Arabidopsis can provide higher Ca tolerance than for B. hygrometrica. Giving that the HSP family is composed of a large number of members, and several other HSP genes had been reported to be induced by external $\mathrm{Ca}$ application (Zhang et al., 2013), further characterization of the interaction of BhDNAJC2 and other HSPs from B. hygrometrica will shine a light to understand the roles of chaperone-mediated protein quality control in the tolerance to high internal $\mathrm{Ca}$ in $B$. hygrometrica.

In summary, by comparing the ranges of high external soluble $\mathrm{Ca}$ that plants could survive, the accumulation and distribution patterns of $\mathrm{Ca}$ in different tissues and cells under various levels of external $\mathrm{Ca}$, distinct strategies to cope with high Ca environment were sketched in two karst-habiting Gesneriaceae species L. pauciflorus and B. hygrometica. Further characterization of the tolerant mechanisms to high internal $\mathrm{Ca}$ in $B$. hygrometrica will provide resource genes for biogeneration of Ca-rich crops and vegetables, whereas the assessment of the molecular basis for controlling $\mathrm{Ca}$ levels in crucial tissues in L. pauciflorus will facilitate the biotechnological breeding of crops that could improve agriculture and ecology in karst regions.

\section{ACKNOWLEDGMENTS}

We thank Feiteng Ji, Huikun Duan, Liancheng Huang, Lanjun Zhang for help in collecting and culturing plants. We thank Jingquan Li for help in operating confocal microscopy. This work was supported by National Natural Science Foundation of China (No. 30970431) and National Basic Research Program of China (973 Program) (No. 2006CB403200).

\section{SUPPLEMENTARY MATERIAL}

The Supplementary Material for this article can be found online at: http://www.frontiersin.org/journal/10.3389/fpls.2014. 00647/abstract

Figure S1 | Growth and physiological parameters of $L$. pauciflorus and $B$. hygrometrica plants treated with 20 (for B. hygrometrica) or $200 \mathrm{mM}$ (for L. pauciflorus) $\mathrm{Ca}\left(\mathrm{NO}_{3}\right)_{2}, \mathrm{CaCl}_{2}$, and $\mathrm{Mg}\left(\mathrm{NO}_{3}\right)_{2}$ for $\mathbf{7}$ days, respectively. (A) The growth of $L$. pauciflorus. Scale bar $=1 \mathrm{~cm}$. (B) The growth of B. hygrometrica. Scale bar $=1 \mathrm{~cm}$. (C) Net photosynthetic rates, relative water contents, osmolalities of leaves of $L$. pauciflorus and $B$. hygrometrica plants. The mean $\pm \mathrm{SD}$ is shown $(n=3)$. The different lowercase letters on the bars indicate significantly different means $(P<0.05)$.

\section{REFERENCES}

Aguilar-Hernandez, H. S., Santos, L., Leon-Galvan, F., Barrera-Pacheco, A., EspitiaRangel, E., De Leon-Rodriguez, A., et al. (2011). Identification of calcium stress induced genes in amaranth leaves through suppression subtractive hybridization. J. Plant Physiol. 168, 2102-2109. doi: 10.1016/j.jplph.2011.06.006

Ajjawi, I., Coku, A., Froehlich, J. E., Yang, Y., Osteryoung, K. W., Benning, C., et al. (2011). A J-like protein influences fatty acid composition of chloroplast lipids in Arabidopsis. PLoS ONE 6:e25368. doi: 10.1371/journal.pone.0025368

Albrechtova, J. T. P., Heilscher, S., Leske, L., Walczysko, P., and Wagner, E. (2003). Calcium and $\mathrm{pH}$ patterning at the apical meristem are specifically altered by photoperiodic flower induction in Chenopodium spp. Plant Cell Env. 26, 1985-1994. doi: 10.1046/j.0016-8025.2003.01114.x

Beckett, M., Loreto, F., Velikova, V., Brunetti, C., Di Ferdinando, M., Tattini, M., et al. (2012). Photosynthetic limitations and volatile and non-volatile isoprenoids in the poikilochlorophyllous resurrection plant Xerophyta humilis during dehydration and rehydration. Plant Cell Env. 35, 2061-2074. doi: 10.1111/j.1365-3040.2012.02536.x 
Brand, J. J., and Becker, D. W. (1984). Evidence for direct roles of calcium in photosynthesis. J. Bioenerg. Biomembr. 16, 239-249. doi: 10.1007/BF00744278

Busse, J. S., and Palta, J. P. (2006). Investigating the in vivo calcium transport path to developing potato tuber using ${ }^{45} \mathrm{Ca}$ : a new concept in potato tuber calcium nutrition. Physiol. Plant. 128, 313-323. doi: 10.1111/j.1399-3054.2006.00741.x

Cao, J., Yuan, D., and Pan, G. (2003). Some soil features in karst ecosystem. Adv. Earth Sci. 18, 37-44.

Chan, C. W., Schorrak, L. M., Smith, R. K. Jr., Bent, A. F., and Sussman, M. R. (2003). A cyclic nucleotide-gated ion channel, CNGC2, is crucial for plant development and adaptation to calcium stress. Plant Physiol. 132, 728-731. doi: 10.1104/pp.102.019216

Chen, K. M., Holmstrom, M., Raksajit, W., Suorsa, M., Piippo, M., and Aro, E. M. (2010). Small chloroplast-targeted DnaJ proteins are involved in optimization of photosynthetic reactions in Arabidopsis thaliana. BMC Plant Biol. 10:43. doi: 10.1186/1471-2229-10-43

Chen, S., Zhang, Z., Wang, B., Zhu, Y., Gong, Y., Sun, D., et al. (in press). Cloning, expression and functional analysis of a J-domain protein coding gene, BhDNAJC2, from the resurrection plant Boea hygrometrica. Chin. Bull. Bot.

Chong, L. P., Wang, Y., Gad, N., Anderson, N., Shah, B., and Zhao, R. (in press). A highly charged region in the middle domain of plant endoplasmic reticulum (ER)-localized heat-shock protein 90 is required for resistance to tunicamycin or high calcium-induced ER stresses. J. Exp. Bot. doi: 10.1093/jxb/eru403

Conn, S., and Gilliham, M. (2010). Comparative physiology of elemental distributions in plants. Ann. Bot. 105, 1081-1102. doi: 10.1093/aob/mcq027

Conn, S. J., Gilliham, M., Athman, A., Schreiber, A. W., Baumann, U., Moller, I., et al. (2011). Cell-specific vacuolar calcium storage mediated by CAX1 regulates apoplastic calcium concentration, gas exchange, and plant productivity in Arabidopsis. Plant Cell 23, 240-257. doi: 10.1105/tpc.109.072769

Dayod, M., Tyerman, S. D., Leigh, R. A., and Gilliham, M. (2010). Calcium storage in plants and the implications for calcium biofortification. Protoplasma 247, 215-231. doi: 10.1007/s00709-010-0182-0

Edelmann, L. (2002). Freeze-dried and resin-embedded biological material is well suited for ultrastructure research. J. Microsc. 207, 5-26. doi: 10.1046/j.13652818.2002.01033.x

Fernandez-Garcia, N., Lopez-Perez, L., Hernandez, M., and Olmos, E. (2009). Role of phi cells and the endodermis under salt stress in Brassica oleracea. New Phytol. 181, 347-360. doi: 10.1111/j.1469-8137.2008.02674.x

Gechev, T. S., Dinakar, C., Benina, M., Toneva, V., and Bartels, D. (2012). Molecular mechanisms of desiccation tolerance in resurrection plants. Cell. Mol. Life Sci. 69, 3175-3186. doi: 10.1007/s00018-012-1088-0

Gilliham, M., Dayod, M., Hocking, B. J., Xu, B., Conn, S. J., Kaiser, B. N., et al. (2011). Calcium delivery and storage in plant leaves: exploring the link with water flow. J. Exp. Bot. 62, 2233-2250. doi: 10.1093/jxb/err111

Gunter, C. C., and Palta, J. P. (2008). Exchangeable soil calcium may not reliably predict in-season calcium requirements for enhancing potato tuber calcium concentration. Am. J. Potato Res. 85, 324-331. doi: 10.1007/s12230-008-9025-3

Hoagland, D. R., and Arnon, D. I. (1950). The Water-Culture Method for Growing Plants Without Soil. Vol. 347. Berkeley, CA: California Agricultural Experiment Station.

Ji, F., Li, N., and Deng, X. (2009). Calcium content and high calcium adaption of plants in karst areas of China. Chin. J. Plant Ecol. 33, 926-935. doi: 10.3773/j.issn.1005-264x.2009.05.012

Jiang, G., Wang, Z., Shang, H., Yang, W., Hu, Z., Phillips, J., et al. (2007). Proteome analysis of leaves from the resurrection plant Boea hygrometrica in response to dehydration and rehydration. Planta 225, 1405-1420. doi: 10.1007/s00425-0060449-z

Kampinga, H. H., and Craig, E. A. (2010). The HSP70 chaperone machinery: J proteins as drivers of functional specificity. Nat. Rev. Mol. Cell Biol. 11, 579-592. doi: $10.1038 / \mathrm{nrm} 2941$

Karley, A. J., Leigh, R. A., and Sanders, D. (2000). Where do all the ions go? The cellular basis of differential ion accumulation in leaf cells. Trends Plant Sci. 5, 465-470. doi: 10.1016/S1360-1385(00)01758-1

Kerton, M., Newbury, H. J., Hand, D., and Pritchard, J. (2009). Accumulation of calcium in the centre of leaves of coriander (Coriandrum sativum L.) is due to an uncoupling of water and ion transport. J. Exp. Bot. 60, 227-235. doi: 10.1093/jxb/ern279

Kong, F., Deng, Y., Zhou, B., Wang, G., Wang, Y., and Meng, Q. (2014). A chloroplast-targeted DnaJ protein contributes to maintenance of photosystem II under chilling stress. J. Exp. Bot. 65, 143-158. doi: 10.1093/jxb/ert357
Lee, D. W., Jung, C., and Hwang, I. (2013). Cytosolic events involved in chloroplast protein targeting. Biochim. Biophys. Acta 1833, 245-252. doi: 10.1016/j.bbamcr.2012.03.006

Liu, C., Willmund, F., Whitelegge, J. P., Hawat, S., Knapp, B., Lodha, M., et al. (2005). J-domain protein CDJ2 and HSP70B are a plastidic chaperone pair that interacts with vesicle-inducing protein in plastids 1. Mol. Biol. Cell 16, 1165-1177. doi: 10.1091/mbc.E04-08-0736

Liu, X., Wang, Z., Wang, L., Wu, R., Phillips, J., and Deng, X. (2009). LEA 4 group genes from the resurrection plant Boea hygrometrica confer dehydration tolerance in transgenic tobacco. Plant Sci. 176, 90-98. doi: 10.1016/j.plantsci.2008.09.012

Livak, K. J., and Schmittgen, T. D. (2001). Analysis of relative gene expression data using real-time quantitative PCR and the 2(-Delta Delta C(T)) Method. Methods 25, 402-408. doi: 10.1006/meth.2001.1262

Long, M., Tang, X., Yu, W., Liao, Y., Huang, W., and Qin, R. (2005). Effects of different calcium levels on photosynthesis and protective enzyme activities of melon leaves. Guihaia 25, 77-82.

Lotscher, M., and Hay, M. J. M. (1996). Distribution of phosphorus and calcium from nodal roots of Trifolium repens: the relative importance of transport via xylem or phloem. New Phytol. 133, 445-452. doi: 10.1111/j.14698137.1996.tb01911.x

Lü, P., Cao, J., He, S., Liu, J., Li, H., Cheng, G., et al. (2010). Nano-silver pulse treatments improve water relations of cut rose cv. Movie Star flowers. Postharvest Biol. Technol. 57, 196-202. doi: 10.1016/j.postharvbio.2010.04.003

Malone, M., White, P., and Morales, M. A. (2002). Mobilization of calcium in glasshouse tomato plants by localized scorching. J. Exp. Bot. 53, 83-88. doi: $10.1093 /$ jexbot $/ 53.366 .83$

Mitra, J., Xu, G., Wang, B., Li, M., and Deng, X. (2013). Understanding desiccation tolerance using the resurrection plant Boea hygrometrica as a model system. Front. Plant Sci. 4:446. doi: 10.3389/fpls.2013.00446

Mizuno, N., and Minami, M. (1980). The use of $\mathrm{H}_{2} \mathrm{SO}_{4}-\mathrm{H}_{2} \mathrm{O}_{2}$ for the destruction of plants matter as a preliminary to determination of $\mathrm{N}, \mathrm{K}, \mathrm{Mg}, \mathrm{Ca}, \mathrm{Fe}, \mathrm{Mn}$. Jpn. J. Soil Sci. Plant Nutr. 51, 418-420

Nomura, H., Komori, T., Uemura, S., Kanda, Y., Shimotani, K., Nakai, K., et al. (2012). Chloroplast-mediated activation of plant immune signalling in Arabidopsis. Nat. Commun. 3, 926. doi: 10.1038/ncomms 1926

Olmos, E., and Hellin, E. (1998). Ultrastructural differences of hyperhydric and normal leaves from regenerated carnation plants. Sci. Hortic. 75, 91-101. doi: 10.1016/S0304-4238(98)00096-X

Peng, Y. H., Zhu, Y. F., Mao, Y. Q., Wang, S. M., Su, W. A., and Tang, Z. C. (2004). Alkali grass resists salt stress through high $\left[\mathrm{K}^{+}\right]$and an endodermis barrier to $\mathrm{Na}^{+}$. J. Exp. Bot. 55, 939-949. doi: 10.1093/jxb/erh071

Rodenkirchen, H. (1998). Evidence for a nutritional disorder of Oxalis acetosella L. on acid forest soils. Plant Soil 199, 153-166. doi: 10.1023/A:1004296115612

Silva, D. L. R. D., Honour, S. J., and Mansfield, T. A. (1996). Estimations of apoplastic concentrations of $\mathrm{K}^{+}$and $\mathrm{Ca}^{2+}$ in the vicinity of stomatal guard cells. New Phytol. 134, 463-469. doi: 10.1111/j.1469-8137.1996.tb04363.x

Simmons, K. E., and Kelling, K. A. (1987). Potato responses to calcium application on several soil types. Am. Potato J. 64, 119-136. doi: 10.1007/BF02854208

Song, W. Y., Choi, K. S., Alexis De, A., Martinoia, E., and Lee, Y. (2011). Brassica juncea plant cadmium resistance 1 protein (BjPCR1) facilitates the radial transport of calcium in the root. Proc. Natl. Acad. Sci. U.S.A. 108, 19808-19813. doi: $10.1073 /$ pnas. 1104905108

Storey, R., and Leigh, R. A. (2004). Processes modulating calcium distribution in citrus leaves. An investigation using $\mathrm{x}$-ray microanalysis with strontium as a tracer. Plant Physiol. 136, 3838-3848. doi: 10.1104/pp.104.045674

Tang, R. H., Han, S., Zheng, H., Cook, C. W., Choi, C. S., Woerner, T. E., et al. (2007). Coupling diurnal cytosolic $\mathrm{Ca}^{2+}$ oscillations to the CAS-IP3 pathway in Arabidopsis. Science 315, 1423-1426. doi: 10.1126/science.1134457

Walsh, P., Bursac, D., Law, Y. C., Cyr, D., and Lithgow, T. (2004). The J-protein family: modulating protein assembly, disassembly and translocation. EMBO Rep. 5, 567-571. doi: 10.1038/sj.embor.7400172

Wang, B. S., Yu, S. X., Shi, S. H., Wang, T., Liao, W. B., and Jin, J. H. (2005). The Biodiversity and Sepcies Evolution of Tropical Forest in Hainan Island. Beijing: Science press.

Wang, L., Shang, H., Liu, Y., Zheng, M., Wu, R., Phillips, J., et al. (2009). A role for a cell wall localized glycine-rich protein in dehydration and rehydration of the resurrection plant Boea hygrometrica. Plant Biol. (Stuttg.) 11, 837-848. doi: 10.1111/j.1438-8677.2008.00187.x 
White, P. J. (2001). The pathways of calcium movement to the xylem. J. Exp. Bot. 52, 891-899. doi: 10.1093/jexbot/52.358.891

White, P. J., and Broadley, M. R. (2003). Calcium in plants. Ann. Bot. 92, 487-511. doi: $10.1093 / \mathrm{aob} / \mathrm{mcg} 164$

Yuan, D. (2001). On the karst ecosystem. Acta Geol. Sinica 75, 336-338. doi: 10.1111/j.1755-6724.2001.tb00541.x

Zhang, L., Ji, F., Wang, L., Qi, D., Zhu, Y., and Deng, X. (2012). A small C2-domain protein from the resurrection plant Boea hygrometrica promotes plant responses to abscisic acid. Chin. Bull. Bot. 47, 11-27. doi: 10.3724/SP.J.1259.2012.00011

Zhang, W. H., Rengel, Z., and Kuo, J. (1998). Determination of intracellular $\mathrm{Ca}^{2+}$ in cells of intact wheat roots: loading of acetoxymethyl ester of Fluo-3 under low temperature. Plant J. 15, 147-151. doi: 10.1046/j.1365-313X.1998.00188.x

Zhang, Z., Wang, B., Sun, D., and Deng, X. (2013). Molecular cloning and differential expression of sHSP gene family members from the resurrection plant Boea hygrometrica in response to abiotic stresses. Biologia 68, 651-661. doi: 10.2478/s11756-013-0204-4

Zhao, Y., Xu, T., Shen, C. Y., Xu, G. H., Chen, S. X., Song, L. Z., et al. (2014). Identification of a retroelement from the resurrection plant Boea hygrometrica that confers osmotic and alkaline tolerance in Arabidopsis thaliana. PLoS ONE 9:e98098. doi: 10.1371/journal.pone.0098098

Zienkiewicz, K., Rejon, J. D., Suarez, C., Castro, A. J., De Dios Alche, J., and Rodriguez Garcia, M. I. (2011). Whole-organ analysis of calcium behaviour in the developing pistil of olive (Olea europaea L.) as a tool for the determination of key events in sexual plant reproduction. BMC Plant Biol. 11:150. doi: $10.1186 / 1471-2229-11-150$

Conflict of Interest Statement: The authors declare that the research was conducted in the absence of any commercial or financial relationships that could be construed as a potential conflict of interest.

Received: 18 August 2014; accepted: 02 November 2014; published online: 20 November 2014.

Citation: Li W, Xu F, Chen S, Zhang Z, Zhao Y, Jin Y, Li M, Zhu Y, Liu Y, Yang $Y$ and Deng $X$ (2014) A comparative study on Ca content and distribution in two Gesneriaceae species reveals distinctive mechanisms to cope with high rhizospheric soluble calcium. Front. Plant Sci. 5:647. doi: 10.3389/fpls.2014.00647

This article was submitted to Plant Nutrition, a section of the journal Frontiers in Plant Science.

Copyright () $2014 \mathrm{Li}, \mathrm{Xu}$, Chen, Zhang, Zhao, Jin, Li, Zhu, Liu, Yang and Deng. This is an open-access article distributed under the terms of the Creative Commons Attribution License (CC BY). The use, distribution or reproduction in other forums is permitted, provided the original author (s) or licensor are credited and that the original publication in this journal is cited, in accordance with accepted academic practice. No use, distribution or reproduction is permitted which does not comply with these terms. 